\title{
Chromosome Numbers of Wild Barley
}

By

\section{Shichiro Tanji}

With 4 Textfigures

While I was carrying on experiments in breeding barleys at the University of California, my attention was directed to the cytological study of this plants.

The chromosome number of barley has been reported as seven in haploid, viz fourteen in diploid, by $\operatorname{Nakao}^{1}$ (I9II), Ubisch' (I92I), and $\mathrm{Kihara}^{3}$ (1924).

But there was left some suspection about it, and it was thought that one might happen to find some different number of chromosomes, because there are several types of barleys in respect to morphological characters. Especially I had much interest in the chromosome numbers of the so-called wild barleys (original forms of the cultivated barleys), which no auther has as yet reported.

The materials for these experiments were kindly transferred to me by Prof. Doctor R. E. Clausen and Prof. Doctor P. B. Kennedy.

$I$ have investigated the chromosome number in diploid by the root tips. Chromic acetic urea solution was used for killing the root materials. The sections were cut at seven microns using the Minot microtome.

The preparations were made following the usual paraffin methods and stained by Haidenhain's iron alum haematoxylin.

The following varieties of cultivated barleys were investigated. But no other number of chromosomes could obtained than 14 in diploid as reported by all previous investigaters.
H. vulgare pallidum.
H. distichon nigricans.
H. vulgare nigrum.
H. distichon palmella. 
H. vulgare coeleste.

H. intermedium haxtoni.

H. intermedium mortoni.
$H$. distichon nigrilaxum

$H$. deficiens deficiens.

H. deficiens tridax.

H. deficiens mudideficies.

With much curious expectation, I have studied the chromosome numbers of the wild barleys of the following species:
a) H. spontaneum.
e) H. caespitosum.
b) H. murinum.
f) H. jabatum.
c) H. nodosum.
g) H. gussoneanum.
d) H. pussillum.
h) H. maritimum.

It was regrettable that the last two species $(\mathrm{g}, \mathrm{h})$ failed to germinate, probably due to the age of seeds. The chromosome figures of Hordeum caespitosum and $\mathrm{H}$. jabatum were not clear enough to be drawn in pictures. However it is almost evident that they have I4 chromosomes, but I could not confirm it here. All the other four species have I4 chromosomes quite the same as cultivated barleys. (Figs. a, b, c, d).

a
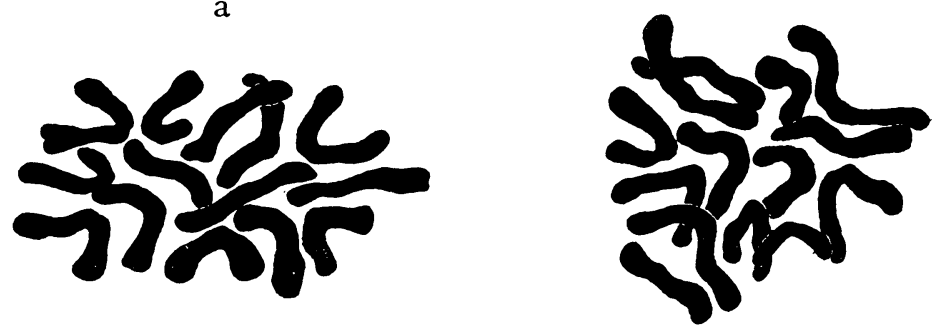

C

d
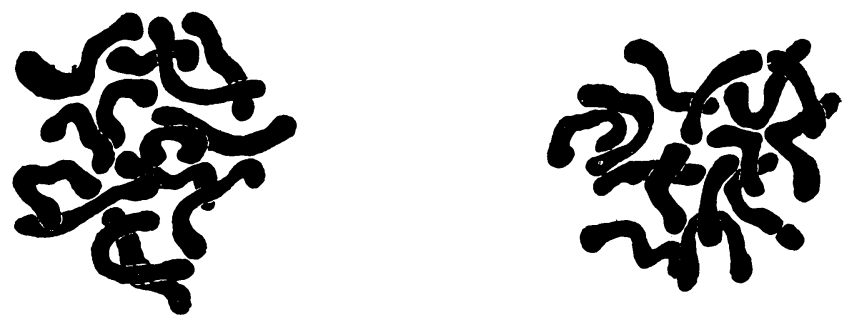

Fig. Camera lucida sketches of chromosomes : magnification 2200. a) $H$. spontaneum, b) H. murinum, c) H. nodosum, d) H. pussillum. 
Among some of the chromosomes both of the cultivated and wild barleys, there were often found one or two pairs which have shorter length. The determination of such detail characters as size and form should be left for further examination.

The work reported here was performed during the period from November 1922 to March 1923, in the Genetics Division of the University of California.

I have to express my sincere gratitude to Prof. Doctor R. E. Clausen who suggested to me this problem and to Doctor Miss Margaret B. Mann who has given me guidance in the technique.

\section{Literature Cited :}

1. Nakao, M. (I9II): Cytological studies on the nuclear division of the pollen mother cells of some cereals and their hybrids. Journ. Coll. Agr. Tohoku Imp. Univ., Sapporo.

2. V. UBisch, G. (192I) : Beitrag zu einer Faktorenanalyse von Gerste. Zeitschr. f. Indukt. Abst. u. Vererb. Lehre. Bd. 25.

3. Kinara, H. (I924): Cytologische und genetische Studien bei wichtigen Getreidearten mit besonderer Rücksicht auf das Verhalten der Chromosomen und die Sterilität in den Bastarden. Memoir Coll. Sci., Kyoto Imp. Univ., Series B, Vol. I, Article I. 